\title{
Intimate partner violence against women in Pakistan: A review of qualitative research
}

\section{Tazeen S. Ali}

Aga Khan University, tazeen.ali@aku.edu

Rida Farhan

Dow University of Health Sciences, Karachi, Pakistan

Michelle Ayub

Dow University of Health Sciences, Karachi, Pakistan

Follow this and additional works at: https://ecommons.aku.edu/pakistan_fhs_mc_chs_chs

Part of the Community Health and Preventive Medicine Commons, and the Domestic and Intimate Partner Violence Commons

\section{Recommended Citation}

Ali, T. S., Farhan, R., Ayub, M. (2020). Intimate partner violence against women in Pakistan: A review of qualitative research. JPMA. The Journal of the Pakistan Medical Association, 70(5), 892-903.

Available at: https://ecommons.aku.edu/pakistan_fhs_mc_chs_chs/755 
SYSTEMATIC REVIEW

\title{
Intimate partner violence against women in Pakistan: a review of qualitative research
}

Tazeen Saeed Ali', Rida Farhan², Michelle Ayub³

\begin{abstract}
Objectives: To consolidate research data and provide an insight into areas that need further research regarding intimate partner violence.

Method: The review targeted qualitative research-based studies done in the English language and conducted in Pakistan from 2008 to 2018 regarding intimate partner violence against women. A thorough search of Google Scholar and PubMed databases was done. Data from each selected article was extracted using a data-extraction template.
\end{abstract}

Results: Of the 2,479 results, $21(0.8 \%)$ articles were selected along with $4(0.16 \%)$ texts from grey literature. An in-depth analysis led to six broad categories: experiences/perspectives of married women facing intimate partner violence; perspectives of married men towards intimate partner violence; perspectives of religious leaders who support the idea of men controlling their wives; societal norms, such as dowry, patriarchy and daughters being considered a burden; impact on women and family as damage to the women's physical and mental health affects not only her but also the society as a whole; and coping strategies used by most women.

Conclusion: The review helps in understanding the common trends and situation of Pakistani women who are exposed to violence, the common limitations faced by researches, and areas which require further research to prevent intimate partner violence.

Keywords: Intimate partner violence, Qualitative, Review, Spousal violence, Domestic violence, Pakistan. (JPMA 70: 892; 2020). https://doi.org/10.5455/JPMA.20759

\section{Introduction}

Intimate partner violence (IPV) is a major public health problem across the world, making it an issue in dire need of being addressed. It is more commonly referred to as domestic violence or spousal violence. The World Health Organisation (WHO) defines IPV as "any behaviour within an intimate relationship that causes physical, psychological or sexual harm to those in the relationship".1 Violence can be conducted against both genders, but the most likely victims are often women. A WHO study based on 10 countries reported women experiencing $15 \%$ to $71 \%$ physical or sexual violence or both, and $20 \%$ to $75 \%$ faced emotional abuse. ${ }^{2}$ Because of IPV, women have become more vulnerable towards physical injury and mental health illnesses, leading to an increased risk of suicidal tendencies. 3

1Department of Community Health Sciences, Aga Khan University, Karachi, Pakistan; School Of Nursing and Midwifery, Aga Khan University, Karachi, Pakistan 2,3Student 3rd Year, Dow Medical College, Dow University of Health Sciences, Karachi, Pakistan. Correspondence: Tazeen Saeed Ali. e-mail: tazeen.ali@aku.edu
Although a global concern, developing countries are more susceptible to the problems caused by IPV. In a country like Pakistan, where patriarchy, poverty, illiteracy and social taboos exist, about $93 \%$ women face sexual violence at least once in their lifetimes. ${ }^{4}$ The most serious forms of violence include 'honour' killings, rape which includes marital rape, acid attacks and stove burning by family members. ${ }^{4}$ These percentages may vary considering they represent only the tip of the iceberg with most cases being unreported as most women choose to accept abuse and remain silent. ${ }^{4} \mathrm{~A}$ study from Pakistan observed spousal violence to be a considerable source of distress especially for women putting them at a risk for suicidal ideation. 5

Even though this topic has been widely researched in Pakistan, most researches tend to be quantitative in nature and stress more on the prevalence percentages between IPV and other factors. On the other hand, qualitative researches usually focus in detail on one aspect in relation to IPV causing the results to be

Vol. 70, No. 5, May 2020 
scattered. A systematic review, using both qualitative and quantitative articles, was done covering the 19852011 period. 6 However, to the best of our knowledge, no recent qualitative systematic analysis has been conducted on the available literature. The current review, therefore, was planned to bridge this gap. The studies used in this review were solely qualitative, with in-depth interviews and focus group discussions (FGDs) being the primary source of data extraction. Grey literature was searched as well and relevant texts were included in the review.

The primary objective of the review was to incorporate all the perspectives and details explored in these qualitative studies to provide a much more extensive picture regarding IPV. The secondary objective was to find the popularly researched factors associated with IPV and those that need to be further researched. This, in turn, would help in identifying successful interventions which may assist in coping with and preventing IPV.

\section{Methodology}

The review targeted qualitative research-based IPV studies done in English language and conducted in Pakistan from 2008 to 2018 . Only studies regarding IPV against women were considered. A few review articles and fact reports by non-governmental organisations (NGOs) were also assessed. Studies conducted in Pakistan as well as those related to Pakistan along with other countries were included in order to examine if root causes play a significant role in contributing to violence against women.

Articles on spousal violence against men or family violence between in-laws or parent and child were not considered. Other articles that were excluded involved quantitative as well as those applying both quantitative and qualitative approaches, articles conducted in other countries or those that related Pakistan with other countries and articles in language other than English. Books that came up on search engines regarding IPV were also ruled out.

For this review, an in-depth literature search using Google Scholar and PubMed databases was performed. The keywords used were 'intimate partner violence', 'violence against women', 'spousal violence', 'domestic violence', 'domestic abuse', 'Pakistan' and 'qualitative'. The search strategy involved Boolean operators to narrow down the search results. Studies were selected using the
Preferred Reporting Items for Systematic Review and Meta-Analysis (PRISMA) as a guideline, i.e., duplicates were first removed followed by screening of titles and abstracts and assessment of full articles which had relevant abstracts. The studies selected were scrutinised to form a data extraction template with all the relevant data such as author, publication year, study year, purpose, design, setting, sampling, sample size, data collection and limitations. The authors, publication year, location and data-collection methods of the grey literature were also recorded. Results of the articles were analysed and broad themes were generated.

For the sake of better understanding of how the different factors arising from the results are interrelated, an ecological model was devised in accordance with the Heise's revised model of $2011 .^{7}$

\section{Results}

Of the 2,479 results, $25(1 \%)$ were selected; $21(0.8 \%)$ articles along with $4(0.16 \%)$ texts from the grey literature (Figure 1). Of the 21 articles, 19(90.4\%) came from Google Scholar and 2(9.5\%) from PubMed (Tables 1). Of the 4 extractions from the grey literature, $1(25 \%)$ was an article and $3(75 \%)$ were reports (Table 2 ). The revised Heise's model comprised 4 overlapping circles: individual level, relationship level, community level, and macrosocial level. The individual level was further divided into women level, male level and between them the conflict arena,

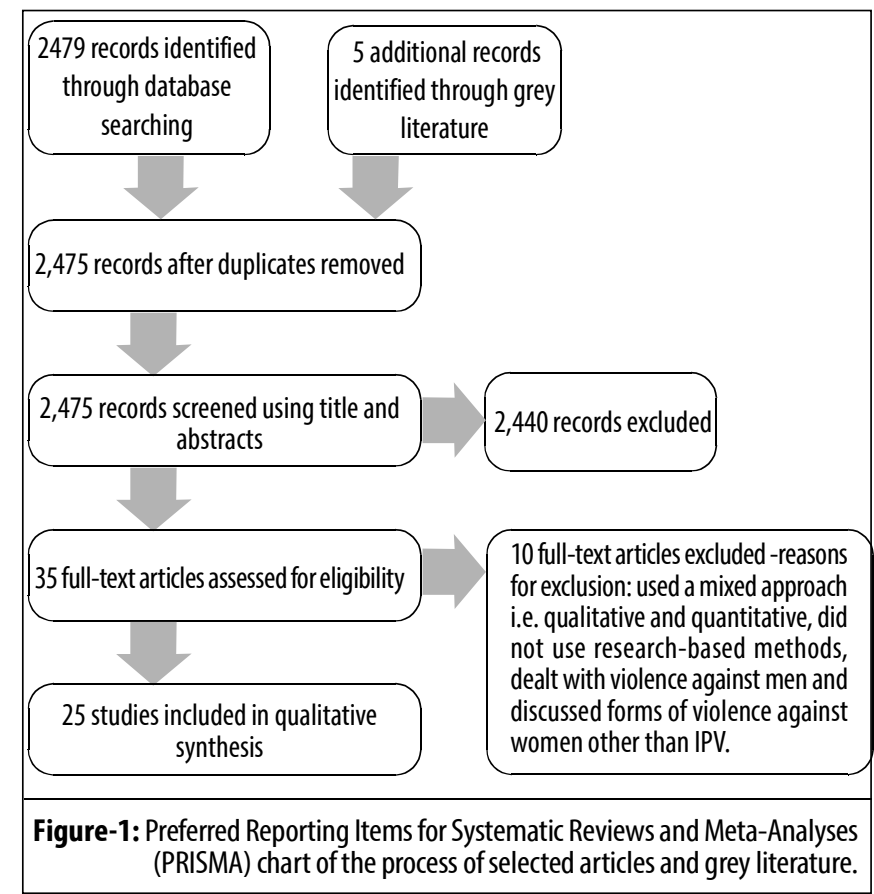


Table-1: Data extracted from the selected articles.

\begin{tabular}{|c|c|c|c|c|c|c|c|}
\hline \multicolumn{2}{|c|}{ S.No. Title } & Authors & $\begin{array}{l}\text { Publication year } \\
\text { (Study year) }\end{array}$ & Purpose & Setting & $\begin{array}{l}\text { Sample size and } \\
\text { data collection }\end{array}$ & Limitations \\
\hline \multicolumn{8}{|c|}{ Qualitative articles using purposive sampling strategy } \\
\hline 1 & $\begin{array}{l}\text { Violence against } \\
\text { Women in } \\
\text { Pakistan: } \\
\text { Perceptions and } \\
\text { Experiences of } \\
\text { Domestic } \\
\text { Violence }\end{array}$ & $\begin{array}{l}\text { Adeel } \\
\text { Khan, Rafat } \\
\text { Hussain } 14\end{array}$ & $\begin{array}{l}2008 \\
(2002-2003)\end{array}$ & $\begin{array}{l}\text { To highlight how } \\
\text { structural, cultural and } \\
\text { individual level issues } \\
\text { intersect in relation to } \\
\text { women's perspective on } \\
\text { domestic violence in } \\
\text { Pakistan }\end{array}$ & $\begin{array}{l}\text { Karachi, } \\
\text { Pakistan }\end{array}$ & $\begin{array}{l}8 \text { key informant } \\
\text { interviews, } 3 \\
\text { focus group } \\
\text { discussions and } \\
10 \text { in depth } \\
\text { interviews }\end{array}$ & $\begin{array}{l}\text { Small sample } \\
\text { size }\end{array}$ \\
\hline 2 & $\begin{array}{l}\text { Women's Perceptions } \\
\text { and Experiences of Sexual } \\
\text { Violence in Marital } \\
\text { Relationships } \\
\text { and Its Effect on } \\
\text { Reproductive Health }\end{array}$ & $\begin{array}{l}\text { Rafat } \\
\text { Hussain, } \\
\text { Adeel Khan12 }\end{array}$ & 2008 & $\begin{array}{l}\text { To provide information } \\
\text { about women's } \\
\text { perceptions and } \\
\text { experiences of sexual } \\
\text { violence within } \\
\text { marriage and its impact } \\
\text { on reproductive health }\end{array}$ & $\begin{array}{l}\text { Low to } \\
\text { middle } \\
\text { income } \\
\text { areas of } \\
\text { Karachi, } \\
\text { Pakistan }\end{array}$ & $\begin{array}{l}8 \text { key informant } \\
\text { interviews, } 24 \\
\text { participants in } 3 \\
\text { focus groups and } \\
10 \text { in depth } \\
\text { interviews (age } \\
20-40 \text { years) }\end{array}$ & $\begin{array}{l}\text { Small sample } \\
\text { size therefore } \\
\text { not } \\
\text { representative }\end{array}$ \\
\hline 3 & $\begin{array}{l}\text { Who am I? } \\
\text { Where am I?" } \\
\text { Experiences of married young } \\
\text { women in a slum } \\
\text { in Islamabad, Pakistan }\end{array}$ & $\begin{array}{l}\text { Saima } \\
\text { Hamid,Eva } \\
\text { Johansson, } \\
\text { Birgitta } \\
\text { Rubenson } 11\end{array}$ & 2009 & $\begin{array}{l}\text { To explore how young } \\
\text { women (13-19 years) } \\
\text { are prepared for married life }\end{array}$ & $\begin{array}{l}\text { Islamabad } \\
\text { slum, } \\
\text { Pakistan }\end{array}$ & $\begin{array}{l}10 \text { in-depth } \\
\text { interviews with } \\
\text { married adolescent } \\
\text { women }\end{array}$ & $\begin{array}{l}\text { Small sample } \\
\text { size therefore } \\
\text { not representative }\end{array}$ \\
\hline 4 & $\begin{array}{l}\text { Coping strategies } \\
\text { adopted by } \\
\text { pregnant women } \\
\text { in Pakistan to } \\
\text { resist spousal } \\
\text { violence }\end{array}$ & $\begin{array}{l}\text { Rubeena Zakar, } \\
\text { Muhammad } \\
\text { Zakria Zakar, } \\
\text { Claudia Hornberg, } \\
\text { Alexander } \\
\text { Kraemer } 31\end{array}$ & $\begin{array}{l}2011 \\
(2008)\end{array}$ & $\begin{array}{l}\text { To understand women's } \\
\text { coping strategies } \\
\text { during pregnancy }\end{array}$ & $\begin{array}{l}\text { Lahore, } \\
\text { Pakistan }\end{array}$ & $\begin{array}{l}21 \text { in-depth } \\
\text { interviews with } \\
\text { pregnant women }\end{array}$ & $\begin{array}{l}\text { Small sample } \\
\text { size }\end{array}$ \\
\hline 5 & $\begin{array}{l}\text { Spousal Violence } \\
\text { against Women } \\
\text { in the Context of } \\
\text { Marital } \\
\text { Inequality: } \\
\text { Perspectives of Pakistani } \\
\text { Religious Leaders }\end{array}$ & $\begin{array}{l}\text { Rubeena Zakar, } \\
\text { Muhammad } \\
\text { Zakria Zakar, } \\
\text { Alexander } \\
\text { Krämer26 }\end{array}$ & $\begin{array}{l}2011 \\
(2008-2009)\end{array}$ & $\begin{array}{l}\text { To document the views } \\
\text { and opinions of } \\
\text { religious leaders } \\
\text { concerning spousal } \\
\text { violence in Lahore, } \\
\text { Pakistan. }\end{array}$ & $\begin{array}{l}\text { Lahore, } \\
\text { Pakistan }\end{array}$ & $\begin{array}{l}14 \text { in-depth } \\
\text { interviews with } \\
\text { male religious } \\
\text { leaders }\end{array}$ & $\begin{array}{l}\text { Small sample - } \\
\text { not Representative } \\
\text { Difficult to ask } \\
\text { probing questions } \\
\text { because of the } \\
\text { religious sensitivity of } \\
\text { the issue }\end{array}$ \\
\hline 6 & $\begin{array}{l}\text { Voices of } \\
\text { Strength and Struggle: } \\
\text { Women's Coping Strategies } \\
\text { Against Spousal } \\
\text { Violence in Pakistan }\end{array}$ & $\begin{array}{l}\text { Rubeena Zakar, } \\
\text { Muhammad } \\
\text { Zakria Zakar, } \\
\text { Alexander } \\
\text { Krämer }^{32}\end{array}$ & $\begin{array}{l}2012 \\
(2008)\end{array}$ & $\begin{array}{l}\text { To explore how women } \\
\text { cope with spousal } \\
\text { violence }\end{array}$ & $\begin{array}{l}\text { Lahore and } \\
\text { Sialkot, } \\
\text { Pakistan }\end{array}$ & $\begin{array}{l}21 \text { in-depth } \\
\text { interviews with } \\
\text { married women } \\
\text { (15-49 years) }\end{array}$ & $\begin{array}{l}\text { Sample was } \\
\text { not representative }\end{array}$ \\
\hline 7 & $\begin{array}{l}\text { Violence } \\
\text { permeating daily } \\
\text { life: a qualitative } \\
\text { study } \\
\text { investigating } \\
\text { perspectives on } \\
\text { violence among } \\
\text { women in } \\
\text { Karachi, Pakistan }\end{array}$ & $\begin{array}{l}\text { Tazeen S Ali, } \\
\text { Gunilla Krantz, } \\
\text { Ingrid Mogren } 10\end{array}$ & $\begin{array}{l}2012 \\
(2010)\end{array}$ & $\begin{array}{l}\text { To explore how married } \\
\text { women perceive } \\
\text { situations that create } \\
\text { family conflicts as well } \\
\text { as women's perceptions } \\
\text { of the consequences of } \\
\text { violence, the adverse } \\
\text { effects on health, and } \\
\text { how to resist violence } \\
\text { within marital life }\end{array}$ & $\begin{array}{l}\text { Five areas } \\
\text { of differing } \\
\text { socioecono } 10 \\
\text { mic status } \\
\text { in urban } \\
\text { Karachi, } \\
\text { Pakistan }\end{array}$ & $\begin{array}{l}\text { Focus group } \\
\text { discussions with } \\
28 \text { women (age } \\
20-60 \text { years) }\end{array}$ & $\begin{array}{l}\text { Small sample } \\
\text { size consisted } \\
\text { of only } \\
\text { married } \\
\text { women }\end{array}$ \\
\hline 8 & $\begin{array}{l}\text { Dowry practices } \\
\text { and their negative } \\
\text { consequences from a female } \\
\text { perspective in Karachi, Pakistan } \\
\text {-a qualitative study }\end{array}$ & $\begin{array}{l}\text { Tazeen } \\
\text { Saeed Ali, } \\
\text { Gunnhildur } \\
\text { Árnadóttir, } \\
\text { Asli Kulane9 }\end{array}$ & $\begin{array}{l}2013 \\
(2010)\end{array}$ & $\begin{array}{l}\text { To see the opinion of } \\
\text { women in terms of } \\
\text { pattern, demand and } \\
\text { negative effects of } \\
\text { dowry }\end{array}$ & $\begin{array}{l}\text { Urban } \\
\text { Karachi, } \\
\text { Pakistan }\end{array}$ & $\begin{array}{l}28 \text { women in five } \\
\text { focus group } \\
\text { discussions }\end{array}$ & $\begin{array}{l}\text { All authors not } \\
\text { present at the } \\
\text { time of focus } \\
\text { group } \\
\text { discussions }\end{array}$ \\
\hline 9 & $\begin{array}{l}\text { Men's Beliefs and Attitudes } \\
\text { Toward Intimate Partner } \\
\text { Violence Against Women in } \\
\text { Pakistan }\end{array}$ & $\begin{array}{l}\text { Rubeena Zakar, } \\
\text { Muhammad } \\
\text { Zakria Zakar, } \\
\text { Alexander } \\
\text { Kraemer23 }\end{array}$ & $\begin{array}{l}2013 \\
(2008)\end{array}$ & $\begin{array}{l}\text { To explore the beliefs } \\
\text { and attitudes } \\
\text { of men toward IPV } \\
\text { against women }\end{array}$ & $\begin{array}{l}\text { Lahore and } \\
\text { Sialkot, } \\
\text { Pakistan }\end{array}$ & $\begin{array}{l}8 \text { in-depth } \\
\text { interviews and } 4 \\
\text { focus group } \\
\text { discussions }\end{array}$ & $\begin{array}{l}\text { The sample } \\
\text { was not } \\
\text { representative } \\
\text { - confined to } \\
\text { limited area }\end{array}$ \\
\hline
\end{tabular}

Continued on next page ........... 
Table-1: Continued from previous page .........

\begin{tabular}{|c|c|c|c|c|c|c|c|}
\hline \multicolumn{2}{|c|}{ S.No. Title } & \multirow{2}{*}{$\begin{array}{l}\text { Authors } \\
\text { Muazzam } \\
\text { Nasrullah, } \\
\text { Rubeena Zakar, } \\
\text { Muhammad } \\
\text { Zakria Zakar, } \\
\text { Safdar Abbas, } \\
\text { Rabia Safdar, } \\
\text { Mahwish Shaukat, } \\
\text { Alexander Krämer }{ }^{1}\end{array}$} & \multirow{2}{*}{$\begin{array}{l}\begin{array}{l}\text { Publication year } \\
\text { (Study year) }\end{array} \\
2014 \\
(2013) \\
17\end{array}$} & \multirow{2}{*}{$\begin{array}{l}\text { Purpose } \\
\text { To describe women's } \\
\text { knowledge and attitude } \\
\text { towards child marriage } \\
\text { practice who } \\
\text { themselves were } \\
\text { married as children }\end{array}$} & \multirow{2}{*}{$\begin{array}{l}\text { Setting } \\
\text { Urban } \\
\text { slums of } \\
\text { Lahore } \\
\text { Pakistan }\end{array}$} & \multirow{2}{*}{$\begin{array}{l}\begin{array}{l}\text { Sample size and } \\
\text { data collection }\end{array} \\
\begin{array}{l}19 \text { in-depth } \\
\text { interviews with } \\
\text { married women }\end{array} \\
\end{array}$} & \multirow{2}{*}{$\begin{array}{l}\text { Limitations } \\
\text { Sample size } \\
\text { not } \\
\text { representative }\end{array}$} \\
\hline 10 & $\begin{array}{l}\text { Knowledge and } \\
\text { attitude towards } \\
\text { child marriage } \\
\text { practice among } \\
\text { women married } \\
\text { as children-a } \\
\text { qualitative study } \\
\text { in urban slums of } \\
\text { Lahore, Pakistan }\end{array}$ & & & & & & \\
\hline 11 & $\begin{array}{l}\text { Circumstances } \\
\text { leading to intimate partner } \\
\text { violence against } \\
\text { women married as children: } \\
\text { a qualitative study in Urban } \\
\text { Slums of Lahore, Pakistan }\end{array}$ & $\begin{array}{l}\text { Muazzam } \\
\text { Nasrullah, } \\
\text { Rubeena Zakar, } \\
\text { Muhammad } \\
\text { Zakria Zakar, } \\
\text { Safdar Abbas, } \\
\text { Rabia Safdar }{ }^{16}\end{array}$ & $\begin{array}{l}2015 \\
(2013)\end{array}$ & $\begin{array}{l}\text { To describe the types } \\
\text { and circumstances of } \\
\text { IPV against women } \\
\text { who were married as } \\
\text { children }\end{array}$ & $\begin{array}{l}\text { Urban } \\
\text { slums of } \\
\text { Lahore, } \\
\text { Pakistan }\end{array}$ & $\begin{array}{l}19 \text { in- depth } \\
\text { interviews with } \\
\text { married women }\end{array}$ & $\begin{array}{l}\text { Selection bias } \\
\text { and study not } \\
\text { representative }\end{array}$ \\
\hline 12 & $\begin{array}{l}\text { Perceptions of } \\
\text { Emotional Abuse with } \\
\text { Respect to Depression, } \\
\text { Anxiety and Low } \\
\text { Self-Esteem among Pakistani } \\
\text { Women from Low Income } \\
\text { Families }\end{array}$ & $\begin{array}{l}\text { Dr. Mona } \\
\text { Aeysha } \\
\text { Khalid } 13\end{array}$ & 2015 & $\begin{array}{l}\text { To discuss intimate } \\
\text { partner abuses, with } \\
\text { respect to its } \\
\text { implications within the } \\
\text { specific culture of Pakistan }\end{array}$ & Pakistan & $\begin{array}{l}30 \text { women } \\
\text { interviewed, } \\
\text { observed and } \\
\text { surveyed - a } \\
\text { longitudinal study }\end{array}$ & ---- \\
\hline 13 & $\begin{array}{l}\text { Not managing } \\
\text { expectations: a grounded } \\
\text { theory of intimate } \\
\text { partner violence from } \\
\text { the perspective of } \\
\text { Pakistani people }\end{array}$ & $\begin{array}{l}\text { Parveen } \\
\text { Azam Ali, } \\
\text { Alicia O'Cathain, } \\
\text { and Elizabeth } \\
\text { Croot } 18\end{array}$ & 2016 & $\begin{array}{l}\text { To explore the social } \\
\text { process behind the } \\
\text { phenomenon of IPV } \\
\text { from the perspective of } \\
\text { Pakistani people living } \\
\text { in and outside Pakistan }\end{array}$ & $\begin{array}{l}\text { Karachi, } \\
\text { Pakistan } \\
\text { and } \\
\text { Sheffield, } \\
\text { UK }\end{array}$ & $\begin{array}{l}\text { In-depth } \\
\text { interviews with } \\
20 \text { women from } \\
\text { Pakistan and } 21 \\
\text { from UK (20-62 } \\
\text { years) }\end{array}$ & $\begin{array}{l}\text { Testing not } \\
\text { sufficient to } \\
\text { establish } \\
\text { applicability }\end{array}$ \\
\hline 14 & $\begin{array}{l}\text { Why women } \\
\text { suffer domestic } \\
\text { violence in silence: } \\
\text { Web-based responses } \\
\text { to a blog }\end{array}$ & $\begin{array}{l}\text { Salima } \\
\text { Muhammad } \\
\text { Farooq, } \\
\text { Tazeen Saeed Ali, } \\
\text { Yasmin Parpio, } \\
\text { Nasreen Lalani, } \\
\text { Muecke Marjorie }{ }^{15}\end{array}$ & $\begin{array}{l}2017 \\
(2011) \\
5\end{array}$ & $\begin{array}{l}\text { To explore perceptions } \\
\text { regarding contributing } \\
\text { factors to domestic } \\
\text { violence among women }\end{array}$ & $\begin{array}{l}\text { Worldwide } \\
\text { (80\% Pakistani } \\
\text { women) }\end{array}$ & $\begin{array}{l}\text { Web based } \\
\text { discussion forum } \\
\text { with } 41 \\
\text { respondents }\end{array}$ & $\begin{array}{l}\text { Only } \\
\text { participants } \\
\text { who had } \\
\text { access to the } \\
\text { internet participated } \\
\text { in this study }\end{array}$ \\
\hline 15 & $\begin{array}{l}\text { Earning as } \\
\text { Empowerment?: } \\
\text { The Relationship } \\
\text { Between Paid } \\
\text { Work and Domestic } \\
\text { Violence in Lyari, Karachi }\end{array}$ & $\begin{array}{l}\text { Nida } \\
\text { Kirmani20 }\end{array}$ & 2018 & $\begin{array}{l}\text { To find association } \\
\text { between women } \\
\text { employment in paid } \\
\text { work and their } \\
\text { experience of domestic } \\
\text { violence }\end{array}$ & $\begin{array}{l}\text { Lyari, } \\
\text { Karachi, } \\
\text { Pakistan }\end{array}$ & $\begin{array}{l}\text { Interviews, focus } \\
\text { groups discussions } \\
\text { and participant } \\
\text { observation with } \\
400 \text { residents of } \\
\text { Lyari }\end{array}$ & ------ \\
\hline 16 & $\begin{array}{l}\text { Influences of } \\
\text { Extended Family } \\
\text { on Intimate } \\
\text { Partner Violence: } \\
\text { Perceptions of Pakistanis in } \\
\text { Pakistan and the United Kingdom }\end{array}$ & $\begin{array}{l}\text { Parveen } \\
\text { Azam Ali, } \\
\text { Alicia 0'Cathain, } \\
\text { and Elizabeth } \\
\text { Croot } 30\end{array}$ & 2018 & $\begin{array}{l}\text { To explore perspectives } \\
\text { about the role and } \\
\text { contribution of } \\
\text { husband's and wife's } \\
\text { family in facilitating or } \\
\text { minimizing IPV }\end{array}$ & $\begin{array}{l}\text { Pakistan } \\
\text { (Karachi) } \\
\text { and United } \\
\text { Kingdom } \\
\text { (Sheffield) }\end{array}$ & $\begin{array}{l}\text { Face-to face } \\
\text { interviews with } \\
15 \text { males and } 26 \\
\text { females ( } N=41 \text { ) } \\
-20 \text { from Karachi } \\
\text { and } 21 \text { from Sheffield }\end{array}$ & $\begin{array}{l}\text { Data was } \\
\text { collected from } \\
\text { limited area }\end{array}$ \\
\hline \multicolumn{8}{|c|}{ Qualitative articles using snowball sampling } \\
\hline 17 & $\begin{array}{l}\text { Intimate partner } \\
\text { violence against } \\
\text { women and its related } \\
\text { immigration stressors in } \\
\text { Pakistani immigrant } \\
\text { families in Germany }\end{array}$ & $\begin{array}{l}\text { Rubeena Zakar, } \\
\text { Muhammad } \\
\text { ZZakar, } \\
\text { Thomas Faist, } \\
\text { Alexander } \\
\text { Kraemer } 19\end{array}$ & 2012 & $\begin{array}{l}\text { To examine the Pakistani } \\
\text { immigrant women's perceptions } \\
\text { about and experiences of IPV } \\
\text { especially after migration to } \\
\text { Germany and how various } \\
\text { immigration stressors could } \\
\text { influence familial relations } \\
\text { in the host country }\end{array}$ & $\begin{array}{l}\text { Bielefeld, } \\
\text { Osnabruck } \\
\text { and Herford, } \\
\text { Germany }\end{array}$ & $\begin{array}{l}32 \text { in-depth } \\
\text { interviews with } \\
\text { married women } \\
\text { (22-48 years of age) }\end{array}$ & $\begin{array}{l}\text { Snowball sampling } \\
\text { used causing } \\
\text { sampling bias } \\
\text { Sample size consisted } \\
\text { only women and was } \\
\text { confined to limited } \\
\text { areas }\end{array}$ \\
\hline
\end{tabular}

Continued on next page ........... 
Table-1: Continued from previous page .........

\begin{tabular}{|c|c|c|c|c|c|c|c|}
\hline \multicolumn{2}{|c|}{ S.No. Title } & \multirow{2}{*}{$\begin{array}{l}\text { Authors } \\
\text { Hina Sultan, } \\
\text { Amina Obaid } \\
\text { Khawaja, } \\
\text { Tehziba Kousir18 }\end{array}$} & \multirow{2}{*}{$\begin{array}{l}\text { Publication year } \\
\text { (Study year) }\end{array}$} & \multirow{2}{*}{$\begin{array}{l}\text { Purpose } \\
\text { To explore the nature of } \\
\text { spousal abuse in } \\
\text { Pakistani women, the } \\
\text { feelings, thoughts and } \\
\text { behaviors associated } \\
\text { with it and the impact } \\
\text { of the abuse on the women }\end{array}$} & \multirow{2}{*}{$\begin{array}{l}\text { Setting } \\
\text { Lahore, } \\
\text { Pakistan }\end{array}$} & \multirow{2}{*}{$\begin{array}{l}\begin{array}{l}\text { Sample size and } \\
\text { data collection }\end{array} \\
\text { Total } 16 \text { women } \\
\text { (24-45 years) } \\
\text { with } 6 \text { in-depth } \\
\text { interviews and } \\
\text { focus group } \\
\text { discussions }\end{array}$} & \multirow{2}{*}{$\begin{array}{l}\text { Limitations } \\
\text { Small sample } \\
\text { size of only } \\
\text { married } \\
\text { women }\end{array}$} \\
\hline 18 & $\begin{array}{l}\text { Spousal Abuse } \\
\text { among Pakistani } \\
\text { Women: A Thematic } \\
\text { Analysis }\end{array}$ & & & & & & \\
\hline \multicolumn{8}{|c|}{ Qualitative review articles } \\
\hline 19 & $\begin{array}{l}\text { Patriarchy and } \\
\text { Gender-Based } \\
\text { Violence in Pakistan }\end{array}$ & Abdul Hadi28 & 2017 & $\begin{array}{l}\text { Aims to highlight the } \\
\text { sufferings of women in } \\
\text { Pakistan }\end{array}$ & Pakistan & & \\
\hline 20 & $\begin{array}{l}\text { Domestic } \\
\text { violence among } \\
\text { Pakistani women: An } \\
\text { insight into } \\
\text { literature }\end{array}$ & $\begin{array}{l}\text { Azmat J. } \\
\text { Khan, } \\
\text { Tazeen S. } \\
\text { Ali, Ali K. } \\
\text { Khuwaja25 }\end{array}$ & $\begin{array}{l}2009 \\
(1998-2008)\end{array}$ & $\begin{array}{l}\text { To estimate the burden } \\
\text { of domestic violence, } \\
\text { its contributing factors } \\
\text { and strategies based on } \\
\text { literature review for the } \\
\text { prevention and control } \\
\text { of domestic violence }\end{array}$ & Pakistan & & \\
\hline 21 & $\begin{array}{l}\text { Violence against } \\
\text { Women in Pakistan: } \\
\text { A Framework for Analysis }\end{array}$ & $\begin{array}{l}\text { Parveen } \\
\text { Azam Ali, } \\
\text { Maria Irma } \\
\text { Bustamante } \\
\text { Gavino24 }\end{array}$ & 2008 & $\begin{array}{l}\text { An attempt to analyze } \\
\text { the issue of violence } \\
\text { against women using } \\
\text { theories applicable within } \\
\text { the Pakistani context }\end{array}$ & Pakistan & & \\
\hline
\end{tabular}

Table-2: Data extracted from the grey literature.

\begin{tabular}{|c|c|c|c|c|c|}
\hline S.No. & Title & Authors/Publisher & Publication year & Location & Data Collection Methods \\
\hline 1 & Women, Violence and Jirgas & $\begin{array}{l}\text { National } \\
\text { Commission on the } \\
\text { Status of Women } 27\end{array}$ & 2016 & All over Pakistan & $\begin{array}{l}\text { Various reports and } \\
\text { researches. }\end{array}$ \\
\hline 2 & $\begin{array}{l}\text { Gender-Based Violence in } \\
\text { Pakistan }\end{array}$ & Aurat Foundation 29 & 2011 & All over Pakistan & $\begin{array}{l}\text { Primary (semi-structured } \\
\text { interviews) and secondary } \\
\text { (review and analysis) data } \\
\text { collection methods }\end{array}$ \\
\hline 3 & $\begin{array}{l}\text { Domestic Violence against } \\
\text { Women: Prevalence and Men's } \\
\text { Perception in PGRN Districts } \\
\text { of Pakistan }\end{array}$ & Rutgers WPF22 & 2012 & $\begin{array}{l}\text { Three provinces } \\
\text { of Pakistan: } \\
\text { Punjab, Balochistan } \\
\text { and Sindh. }\end{array}$ & $\begin{array}{l}\text { Quantitative and qualitative } \\
\text { method used from both men } \\
\text { and women }\end{array}$ \\
\hline 4 & $\begin{array}{l}\text { Engaging with Boys and } \\
\text { Young Men to Address Gender } \\
\text { Based Violence and Masculinities }\end{array}$ & $\begin{array}{l}\text { Rozan - Islamabad } \\
\text { based NG021 }\end{array}$ & 2011 & $\begin{array}{l}\text { Pre urban } \\
\text { community of } \\
\text { Rawalpindi, Pakistan }\end{array}$ & $\begin{array}{l}\text { Questionnaire \& Training } \\
\text { sessions }\end{array}$ \\
\hline
\end{tabular}

making a total of 6 circles (Figure 2).

An in-depth analysis led to six broad categories: experiences/perspectives of married women facing intimate partner violence; perspectives of married men towards intimate partner violence; perspectives of religious leaders who support the idea of men controlling their wives; societal norms, such as dowry, patriarchy and daughters being considered a burden; impact on women and family as damage to the women's physical and mental health affects not only her but also the society as a whole; and coping strategies used by most women (Table 3).

\section{1) Experiences/Perspectives of married women facing IPV}

The perspectives and problems faced by young married women were discussed by $13(52 \%)$ articles. ${ }^{8-20}$ Most of the women face serious restriction, are denied basic rights ${ }^{18}$ and kept in strict pardah (seclusion). ${ }^{14}$ They are given limited autonomy and provided with limited societal support. They are also not allowed to continue/finish their education, often their activities only being confined to household chores and taking care of the family. ${ }^{13}$ Most women are forced to work in menial low-paid jobs as husband is either unemployed 
Table-3: The six themes and their main points.

\begin{tabular}{|c|c|}
\hline Categories & Main points \\
\hline $\begin{array}{l}1 \text { Experiences/Perspectives } \\
\text { of married women facing } \\
\text { Intimate Partner } \\
\text { Violence } \\
\text { (13 articles) }\end{array}$ & $\begin{array}{l}\text { * Denied education, basic rights and comfort } \\
\text { * Given excessive responsibilities of household chores } \\
\text { and child care } \\
\text { * Either made to work in menial jobs or not allowed to } \\
\text { work at all } \\
\text { * Limited societal support, early marriages, divorce not } \\
\text { an option } \\
\text { * Ridiculed, humiliated and suspected to be involved in } \\
\text { extra-marital affairs by their husbands } \\
\text { * Older women are more submissive and accepting than } \\
\text { the younger ones who feel victimized } \\
\text { * No say regarding family decisions or even their own } \\
\text { decisions } \\
\text { * Forced to keep husband happy and submit to his } \\
\text { sexual demands } \\
\text { * Immigration after marriage induces stress and } \\
\text { isolation due to change in culture }\end{array}$ \\
\hline $\begin{array}{l}2 \text { Perspectives of married } \\
\text { men } \\
\text { (6 articles) }\end{array}$ & $\begin{array}{l}\text { * Expectations of an "Ideal Wife" } \\
\text { * Suspicious of wives, treat them as inferior, police } \\
\text { them and make every decision for them to feel a } \\
\text { sense of power and command } \\
\text { " Financial instability/unemployment or personal } \\
\text { problems causes release of emotions in the form of } \\
\text { violence } \\
\text { * Burdened by the responsibility of providing food, } \\
\text { shelter and protection and feel unnecessarily blamed } \\
\text { for violence } \\
\text { * Torn between mother and wife } \\
\text { * Hold the belief that women who disagree with their } \\
\text { husbands or are unable to give birth to a male child } \\
\text { deserve to be treated violently } \\
\text { * Some believe extramarital relationships to be a sin for } \\
\text { women but not for men }\end{array}$ \\
\hline $\begin{array}{l}3 \text { Perspectives of religious } \\
\text { leaders } \\
\text { (1 article) }\end{array}$ & $\begin{array}{l}\text { * Marital inequality is considered normal and physical } \\
\text { punishment of wife is justified if she doesn't play the } \\
\text { role of an "ideal wife" } \\
\text { * Criticize "modernization" introduced by the Western } \\
\text { culture and the victim for being "too independent" } \\
\text { * Advise women to pray and be patient/ submissive and } \\
\text { preserve their marriage } \\
\text { * Punishment for abusers not considered } \\
\text { * Agreed that Islam has given many rights to women, } \\
\text { but a woman's freedom should be confined within the } \\
\text { boundaries of religion and culture } \\
\text { * Belief in kismet (destiny) regarding happiness in } \\
\text { marriage }\end{array}$ \\
\hline $\begin{array}{l}4 \text { Societal } \\
\text { norms/expectations } \\
\text { (13 articles) }\end{array}$ & $\begin{array}{l}\text { * The burden of dowry on the girl's family } \\
\text { * Child marriages and arranged marriages are common } \\
\text { with family interference and no privacy given to } \\
\text { couples } \\
\text { * Patriarchal society where daughters are considered a } \\
\text { burden and refused the right to proper education } \\
\text { * Spousal violence, honour killings and acid attacks } \\
\text { seen as acceptable } \\
\text { * Jirgas consist of male members hence not in favour of } \\
\text { women } \\
\text { * Lack of awareness about women rights and women } \\
\text { expected to bind the family together even if it is at the } \\
\text { expense of their own well-being }\end{array}$ \\
\hline
\end{tabular}

Table-3: The six themes and their main points.

\begin{tabular}{ll}
\hline Categories & Main points \\
\hline $\begin{array}{l}\text { Impact on women and } \\
\text { family as a whole } \\
\text { (8 articles) }\end{array}$ & * Mental health consequences such as depression, fear, \\
anxiety, low self-esteem and suicidal tendencies \\
& * Physical injuries with risk to foetus in pregnant women \\
& * Menstrual cycle disturbances, miscarriages and difficulty \\
& in child birth especially amongst young girls who are \\
married as soon as they hit puberty & * Children experiencing violence grow up to be \\
disturbed individuals & \\
& * Poor house management with poor upbringing of \\
& children \\
6 Coping strategies used & * Engaging in religious activities \\
by women & * Appeasing the husband \\
(4 articles) & * Avoiding contact with the husband/giving him silent \\
& treatment \\
& * Seeking support from family and other social \\
& networks \\
& * Educated women taking a stand against violence \\
& * Getting a divorce
\end{tabular}

or does not earn enough. ${ }^{20}$ To exacerbate it, they are not given control over their incomes which coupled with increased responsibilities of domestic chores and providing for the family causes strain in their marital life. 20 On the other hand, educated women working at high-paid jobs are made to leave their jobs before marriage because of societal pressures and husband feeling threatened if wife earns more than him. ${ }^{20}$ For many, divorce is not an option, making them feel trapped in an abusive marriage. ${ }^{14}$ Often the younger and goodlooking women are kept under strict check as they are considered more likely by the society to be involved in extra-marital affairs. ${ }^{14}$ Early marriages results in crushed hopes and dreams of young girls and leave them with the responsibilities of marriage with no say in important family decisions. ${ }^{18}$ Younger women are more resentful towards the physical abuse and patriarchal culture compared to the older women. ${ }^{14,20}$ Furthermore, women feel they cannot talk about family matters outside of home as it is looked down upon by society and considered a disgrace to the family's honour. ${ }^{14}$ Most women believe that obeying their husband, even if he is abusive, is the way to please God, hence fulfilling all their demands whether sexual or otherwise. ${ }^{13}$ She is also supposed to keep her husband happy 10,13 and not trigger him to violent acts of abuse. 10 Often husband's need for sex at inappropriate times leads to forced sex and physical violence. 12 It becomes even more embarrassing for the women as their children mature. Women are afraid that they will be abandoned by their 
husbands if they refuse their sexual demands. Men also do not use protection causing unwanted pregnancies and a large family that none of them can afford to take care of. Abortion is not always a possibility as it depends on multiple factors like religious beliefs and family's opinion. To prevent further pregnancies, it is the woman who eventually has to undergo sterilisation. In one case where the husband underwent sterilisation, the wife reported that he became more violent and aggressive with increased sexual demands. During pregnancies, women reported that husbands became physically violent, often leading to miscarriages. Familial support to the women is limited because families feel that excessive intervention could end up in divorce. This, coupled with the fact that sexual violence is a taboo topic, leaves most women enduring the pain in silence. ${ }^{12}$

Most women also believe that men are superior and should be treated as such, thus giving men the right to be abusive. ${ }^{13}$ Women are also expected to stay silent during a fight or any kind of abuse. They are also not allowed to make their own decisions whether it is to go shopping or to get a job. If a woman is earning, she is forced to hand over all her pay to her husband while the husband reserves the right to ridicule and humiliate her at all times. ${ }^{13}$ Using abusive language to address and threaten them is also very common. ${ }^{18}$

One article discussed the problems faced by Pakistani immigrant families in Germany which induced stress and isolation due to change in culture leading to spousal abuse. The greatest loss faced by the women in other countries was the loss of social network and parental support. ${ }^{19}$ Women tend to stay silent in such kinds of abusive relationships for the sake of their reputation and their children's safety and future needs. Silence, patience and wisdom is seen by most women as the key to overpowering a violent husband. ${ }^{19}$

\section{2) Perspectives of married men}

Six (24\%) articles 8,21-25 talked about the perspectives of men towards spousal violence. It was found that men usually have a preconceived notion of an "ideal wife"23 who would cater to his demands and continue his legacy by giving birth to a male child. Men are also suspicious of their wives and feel it is their responsibility to keep them under surveillance. ${ }^{14}$ Most men believe that the women who argue or disagree with the men of the family deserve to be treated violently. In fact, it is a threat to their masculinity if the wife is not under their control.
They even prefer marry uneducated women who wouldn't raise her voice for her rights. Since boys are taught not to show their emotions, they resort to violence as a way of releasing their emotions. For some, it is a way of coping with anger which may be due to financial instability, ${ }^{25}$ unemployment ${ }^{24}$ or a low socioeconomic status. Some men hold a false belief that extramarital relationships are not a sin for men and that they can have multiple wives without their current wife's permission while refusing to accept the rights granted to women by Islam. ${ }^{10}$ If the wife argues or wears clothing that is inappropriate in the eyes of the males, it is thought that she is calling for violence unto herself. ${ }^{10}$ Men also have the burden of providing food, shelter and protection to the family. ${ }^{22}$ In joint families, greater number of family members leads to increased burden on men, making them frustrated and, thus, more prone to violence. ${ }^{8}$ Also, the ongoing arguments between a man's wife and mother forces him to choose sides, causing marital conflict in turn. ${ }^{8}$ To further exaggerate it, they feel they are often unjustly blamed for violence. Men, however, feel they have a right to decide every aspect of their wife's life; from what she is wearing and who she is meeting to getting a job or continuing her education. ${ }^{13}$ They consider women inferior to them and incompetent due to their emotional behaviour and short temper, 23 therefore disregarding their feelings and opinions. ${ }^{13}$ They also expect women to be submissive and force them to stay in seclusion within the boundaries of their home. Majority of the men are addicted to alcohol, even though it is not permissible in Islam, making them violent and aggressive towards their family.

\section{3) Perspectives of religious leaders}

One (4\%) article ${ }^{26}$ gathered the views of religious leaders on the topic of domestic violence. Most leaders considered marital inequality to be the norm and held the belief that the husband should have a commanding position in the household. They were quick to blame women for the violence inflicted on them, criticising the "modernization" of women or women being "too independent". Most of them felt that she deserved "mild violence" if she defied the role of an "ideal wife" but all agreed that serious damage to her health was un-Islamic and illegal. All believed women were given many rights in Islam, but that a woman's freedom must remain confined to the limits of religion and culture. Their only advice to women who were victims of violence

Vol. 70, No. 5, May 2020 
was to pray and remain patient. Proper treatment options or counselling programmes were not considered. They also laid great emphasis on preserving marriage and avoiding divorce.

\section{4) Societal norms/expectations}

Majority of the articles ( $n=13 ; 52 \%)$ mentioned societal and cultural norms as the reasons for violence. ${ }^{8-10,13,15-}$ 17,24,25,27-30 Arranged marriages are common where the couple have hardly known each other before marriage 30 resulting in the husband ignoring his wife, therefore not paying attention to her feelings or thoughts. ${ }^{10}$ Extended families create problems for the newly married couple by giving little to no personal space for them to understand each other, interfering in their marital life by the husband's family complaining to him about the wife and wife's family complaining to her about the husband as well as the husband's family setting unrealistic expectations from their daughter-in-law and vice versa. ${ }^{30}$ These unmet expectations from both ends, combined with wife's difficulty in adjusting to her husband's family leads to problems within the marriage causing IPV. ${ }^{30}$ Furthermore, men are expected to be masculine, which means aggressive and in command, while women are expected to be feminine, meaning fragile and submissive. Therefore, any deviation from these expectations is looked down upon by society. Another common tradition is dowry given by the girl's family.9,10 It is considered a reflection of the socioeconomic status of families, making them a burden on most since women who get lesser dowries feel insecure and are often made to go out and work for the groom's family. It was also seen that men avoided divorcing their wives as they were reluctant to return the dowry which is basically the woman's property. ${ }^{9}$ Physical violence, for example beating the wife publicly, is also seen as acceptable by society 10 and is misconceived to be a religious right granted to man. Often, it is the in-laws who turn the man against his wife in order to keep her in check. ${ }^{14}$

Gender inequality is also common in society where boys get privileges whereas even the basic rights of girls, such as education, suffer, leading to a huge gap between spouses. Moreover, women cannot be members of the jirga. ${ }^{27}$ Child marriages and even forced marriages are common, leading to unhappiness in marriage. Women are also expected by society to keep the family together even if it is at the cost of their own well-being. If a woman's conduct and behaviour goes against the traditional honour code, she is considered to be bringing disgrace to the family and is therefore killed or burnt by the men of the family to protect their honour. ${ }^{28}$ Through such honour killings, men demonstrate their masculinity and even the police refuses to get involved in these situations. ${ }^{28}$ Acid attacks is another troubling phenomenon where men throw acid onto the faces and bodies of their wives to "teach her a lesson" by disfiguring her. It is usually caused by petty marriage or dowry issues. 28

\section{5) Impact on women and family as a whole}

A total of 8(32\%) articles 10,14-18,22,25 discussed the effect on the physical and mental health of women. The abused women were more likely to have a low self-esteem, 14 lack of confidence, increased risk of depression, fear and anxiety as well as suicidal tendencies. ${ }^{10}$ They felt powerless, frustrated, insecure and isolated. ${ }^{10,18}$ Suicide was more common when there were multiple reasons involved; for example, limited income, limited support and frequent cycles of abuse. ${ }^{14}$ Girls who get married as soon as they hit puberty may experience disturbed menstrual cycles, miscarriages and difficulty in childbirth. ${ }^{17}$ There is also a risk to the foetus in pregnant women facing violence 22 as well as serious physical injuries to the women.

The management of the house and proper upbringing of children may also suffer due to the impaired health of women. ${ }^{16}$ Sons who grow up seeing their fathers violent towards the mother are more likely to be violent towards their wives. ${ }^{10,15}$ Similarly, girls who grow up seeing violence towards women become more accepting of violence and start considering it a norm rather than an abnormality. ${ }^{10}$ Furthermore, violence may lead to divorce, breaking the family apart. 10

\section{6) Coping strategies used by women}

Of the total, 4(16\%) articles 19,22,31,32 talked about the coping strategies employed by women. It was seen that abused women engaged frequently in individual religious activities,31,32 appeased the husband or avoided contact with him, ${ }^{32}$ while some resorted to giving the silent treatment in the hope of teaching him a lesson. ${ }^{19}$ Some blamed themselves or denied the existence of violence. $^{32}$ A few of them sought support from their families or other available resources, and some even left their husbands. ${ }^{32}$ Educated females were more likely to 
be aware of their rights and stand up for them. ${ }^{10}$ However, sometimes coping strategies took an adverse turn as a woman's excessive engagement in other activities made the husband feel neglected, causing marital conflict. 31

\section{Discussion}

The aim of this review was to consolidate all the qualitative research done so far on IPV against women in Pakistan. The results clearly show that a lot of situations contribute to violence against women. This discussion uses Heise's model to explain the interrelating factors that contribute to IPV at every level, i.e. individual (male and female), family relations, community and social. At an individual level, most women in Pakistan are willing to endure abuse and show sabr (patience) as a way of accepting their kismet (destiny). ${ }^{14}$ Part of the reason is the low educational level as women with a lower educational level were found to suffer more compared to those who could stand up for their rights 24 and partly due to women witnessing violence in their homes while growing up. Also, by treating men as superior, women have normalised the set gender roles, thus accepting themselves as inferior and giving men the right to be abusive. Men, on the other hand, abuse the power granted to them by women and society, becoming

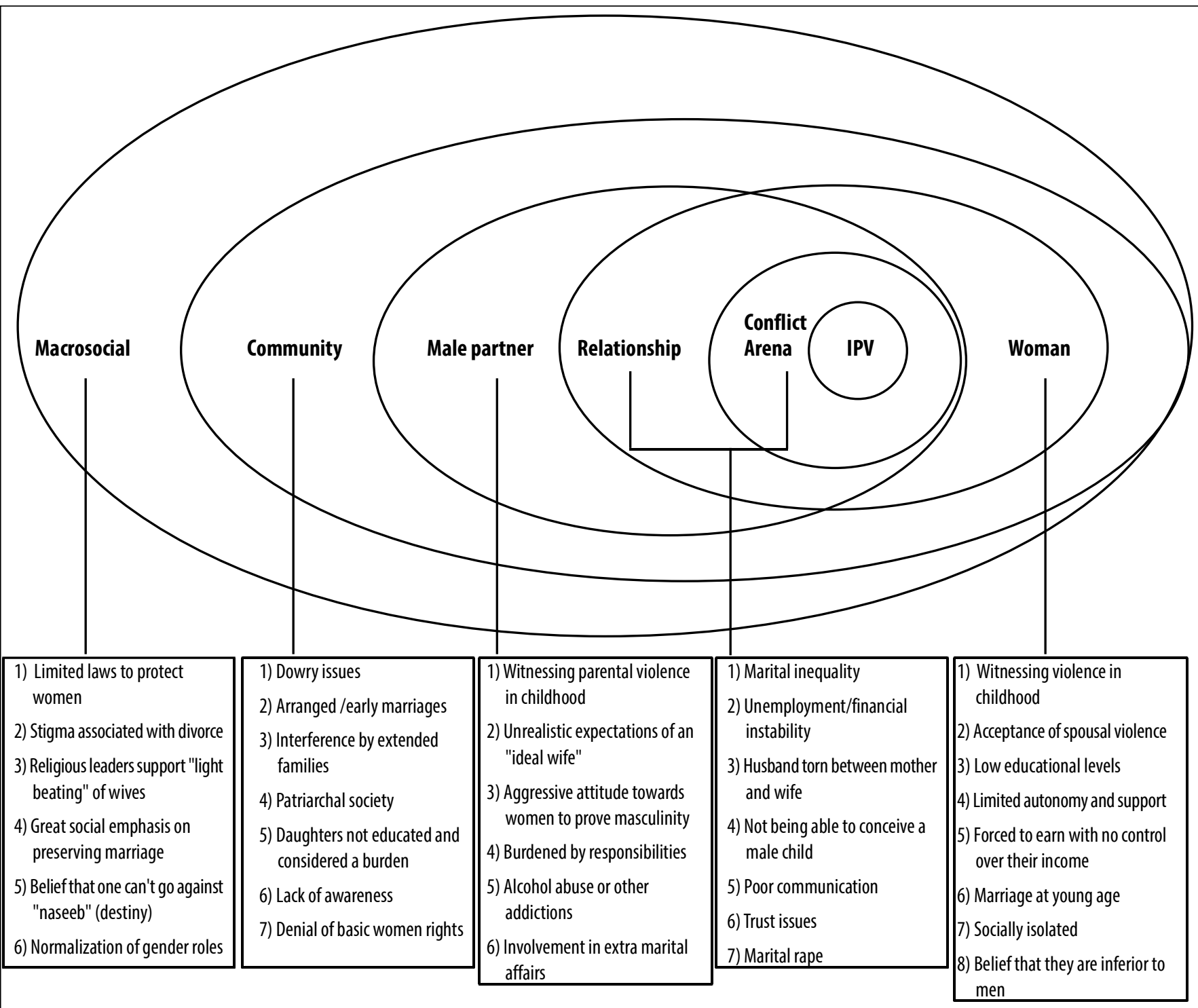

Figure-2: Factors contributing to Intimate Partner Violence (IPV). 
violent and aggressive. Boys who witness parental violence in childhood consider wife-beating as acceptable. Men also have unrealistic expectations from their wife which, when unmet, can be a cause of conflicts. ${ }^{8}$ They enforce pardah (full covering from head to toe) on their wives and limit their interaction with the opposite gender. ${ }^{14}$ On a family level, in-laws, especially mother-in-law and sister-in-law, were found to play a major role in perpetuating violence. 33 Furthermore, poor communication between spouses and decision-making done solely by the husbands weakens the relationship. Children in the family grow up with no proper sense of moral values where the boys think it is okay to hurt girls, while the girls grow up to be submissive and accepting of violence.

On a community level, a major factor which imprisons women in an abusive relationship is the stigma associated with divorce. ${ }^{34}$ Even educated and empowered women stay silent to maintain their respect and image in society as there is immense societal pressure on women to keep their marriage intact.15,20 One of the reasons men were found to avoid giving a divorce was the reluctance to return dowry which legally is a woman's property.

On a macrosocial level, women are given limited rights and access to employment opportunities. Religious leaders and the media support men practising IPV, empowering them in their wrongdoings. These leaders criticise female empowerment as something "modern" which, according to them, is not acceptable in Islam. ${ }^{26}$ Furthermore, they support "light beating" inflicted upon wives, a term whose boundaries are not clearly defined. It was also seen that most people confuse traditional norms with religious beliefs, hence, blindly perceiving it as the Islamic way of life. 18,24

\section{Recommendations}

In the light of the above, it is extremely important, considering the gravity of the situation, to empower and educate women. On an individual level, women must be able to set limits, identify violence and reach out for help. ${ }^{13}$ They should be aware of the rights granted to them by law as well as by Islam. On a family level, good relationships between women and her in-laws could help minimise domestic violence. A husband and wife can work on understanding each other's expectations and maintaining a balanced relationship. ${ }^{8}$ Mothers ought to try not to extend their negative beliefs to their daughters. ${ }^{13}$ Mother-in-laws must try to give personal space to the couple so they can effectively spend time together in understanding each other. 30 On a community level, customs and traditions, such as dowry, arranged marriages and child marriages, should be avoided. Jirgas should either be banned or replaced with a proper judicial system that consists of an equal ratio of men and women in order for decisions to remain unbiased. ${ }^{27}$ On a macrosocial level, there is a need for this issue to be recognised and for the perpetrators to be punished by law. ${ }^{13}$ Improved medical facilities and trained hospital staff to recognise cases of domestic violence as well as support groups and helplines for women to reach out easily for help without any fear of the consequences can prove beneficial in the long run to prevent IPV. Putting victims of spousal violence under psychiatric care for the treatment of depression and anxiety will also help to lower the suicide rates. Equal employment opportunities and laws to protect women must be immediately passed. Women police officers should take control of the situation as there have been cases of harassment by male police officers towards helpless women. ${ }^{28}$ Positive coping strategies can also be discussed by the media so that women may know how to deal with such a situation. Coping strategies adopted by women was an area of interest where little research was found.

Men, religious leaders and women of the elder generation must be counselled on the rights of women and the dangers of IPV. However, this area requires more research to test ways to educate politicians and religious leaders. It was also observed that limitations of most articles involved only the female perspective, small sample sizes and localisation to one area. These limitations can be overcome by future studies on a larger scale and covering various areas of Pakistan, especially the rural areas.

\section{Strengths and limitations}

This review attempted to provide an in-depth analysis of qualitative studies related to IPV, and it does have its limitations. Articles in languages other than English and publications in journals not indexed in the databases used were not considered. Since IPV is a hushed-up topic in Pakistani society, a complete picture may not have been presented due to women and their families holding back important data. Most of the articles used were from 
the major cities of Lahore, Karachi and Islamabad, hence, missing out on rural areas. Nonetheless, this review encompasses the major themes influencing IPV in Pakistan, and provides an understanding of how future researches can be carried out.

\section{Conclusion}

Intimate partner violence is contagious and that is affecting the lives of Pakistani individuals, both men and women. A few qualitative reviews focussing on the people's perspective towards IPV and its association factors have been conducted. This review merged all these association factors to form a complete picture, revealing the commonly found themes like experiences and perspectives of married women facing IPV, perspectives of married men, societal and cultural norms and impact on women and family as a whole. Considering the data, there is an urgent need to prevent IPV. Little measures such as teaching women arts and craft skills to be able to earn from their homes would go a long way in case they choose to seek divorce. Stigma around IPV must be removed through the help of media and the government so women can comfortably discuss these topics without feeling ashamed or embarrassed. Furthermore, very little literature was found on coping strategies adopted by women and perspectives of religious leaders.

\section{Disclaimer: None. \\ Conflict of Interest: None. Source of Funding: None.}

\section{References}

1. O'Doherty L, Hegarty K, Ramsay J, Davidson LL, Feder G, Taft A. Screening women for intimate partner violence in healthcare settings. Cochrane database of systematic reviews. 2015.

2. Beyene AS, Chojenta C, Roba HS, Melka AS, Loxton D. Genderbased violence among female youths in educational institutions of Sub-Saharan Africa: a systematic review and meta-analysis. Systematic reviews. 2019;8:59.

3. Pandey S. Physical or sexual violence against women of childbearing age within marriage in Nepal: Prevalence, causes, and prevention strategies. International Social Work. 2016;59: 803-20.

4. Agha N, Ahmed Z. Prevalence and Nature of Violence against Women in Pakistan: A Six-month Content Analysis of a Pakistani newspaper. Pakistan Journal of Criminology. 2018;10:100.

5. Boahen-Boaten BB, White RG, O'Connor RC. Suicide in Low-and Middle-Income Countries. The Palgrave Handbook of Sociocultural Perspectives on Global Mental Health: Springer; 2017. p. 351-82.

6. Ali PA, Naylor PB, Croot E, O'Cathain A. Intimate partner violence in Pakistan: A systematic review. Trauma, Violence, \& Abuse. 2015;16:299-315.

7. Molin J. Preventing Gender-Based Violence Post Disasters: Building the capacity of humanitarian actors in the Philippines to engage with men and boys to reduce the risks of perpetration of violence. 2018.

8. Ali PA, O'Cathain A, Croot E. Not managing expectations: a grounded theory of intimate partner violence from the perspective of Pakistani people. Journal of interpersonal violence. 2017:0886260516672939.

9. Ali TS, Árnadóttir G, Kulane A. Dowry practices and their negative consequences from a female perspective in Karachi, Pakistan-a qualitative study. Health. 2013;5(7D):84.

10. Ali TS, Krantz G, Mogren I. Violence permeating daily life: a qualitative study investigating perspectives on violence among women in Karachi, Pakistan. International journal of women's health. 2012; 4: 577.

11. Hamid S, Johansson E, Rubenson B. "Who am I? Where am I?" Experiences of married young women in a slum in Islamabad, Pakistan. BMC Public Health. 2009;9:265.

12. Hussain R, Khan A. Women's perceptions and experiences of sexual violence in marital relationships and its effect on reproductive health. Health care for women international. 2008; 29: 468-83.

13. Khalid MA. Perceptions of Emotional Abuse with Respect to Depression, Anxiety and Low Self-Esteem among Pakistani Women from Low Income Families. Mediterranean Journal of Social Sciences. 2015; 6: 223.

14. Khan A, Hussain R. Violence against women in Pakistan: Perceptions and experiences of domestic violence. Asian Studies Review. 2008;32:239-53.

15. Muhammad-Farooq S, Saeed-Ali T, Parpio Y, Lalani N, Marjorie M Why women suffer domestic violence in silence: Web-based responses to a blog. Nursing Practice Today. 2017;4:203-11.

16. Nasrullah M, Zakar R, Zakar MZ, Abbas S, Safdar R. Circumstances leading to intimate partner violence against women married as children: a qualitative study in Urban Slums of Lahore, Pakistan. BMC international health and human rights. 2015;15:23.

17. Nasrullah M, Zakar R, Zakar MZ, Abbas S, Safdar R, Shaukat M, et al. Knowledge and attitude towards child marriage practice among women married as children-a qualitative study in urban slums of Lahore, Pakistan. BMC public health. 2014;14:1148.

18. Sultan H, Khawaja AO, Kousir T. Spousal Abuse among Pakistani Women: A Thematic Analysis. Pakistan Journal of Social and Clinical Psychology. 2016;14:33-41.

19. Zakar R, Zakar MZ, Faist T, Kraemer A. Intimate partner violence against women and its related immigration stressors in Pakistani immigrant families in Germany. SpringerPlus. 2012;1: 5.

20. Kirmani N. Earning as Empowerment?: The Relationship Between Paid Work and Domestic Violence in Lyari, Karachi. Rethinking New Womanhood: Springer; 2018. p. 169-87.

21. Engaging With Boys and Young Men to Address Gender Based Violence and Masculinities: Rozan; 2011 [11/06/18]. Available from: http://www.rozan.org/sites/default/files/Module.pdf.

22. Qayyum K, Gul S, Ploem R. Domestic Violence against Women: Prevalence and Men's Perception in PGRN Districts of Pakistan. 2012.

23. Zakar R, Zakar MZ, Kraemer A. Men's beliefs and attitudes toward intimate partner violence against women in Pakistan. Violence against women. 2013;19: 246-68.

24. Ali PA, Gavino MIB. Violence against women in Pakistan: a framework for Analysis. Journal-Pakistan Medical Association. 2008;58:198.

25. Khan AJ, Ali TS, Khuwaja AK. Domestic violence among Pakistani women: an insight into literature. Isra Medical Journal. 2009;1:54

26. Zakar R, Zakar MZ, Krämer A. Spousal violence against women in the context of marital inequality: Perspectives of Pakistani religious leaders. Int J Conflict Violence 2011; 5: 371-84

27. Brohi N. Women, Violence and Jirgas. Islamabad, Pakistan: 2016

28. Hadi A. Patriarchy and Gender-Based Violence in Pakistan. Eur J Soc Sci Educ Res 2017; 10: 297-304. 
29. Parveen R. Gender-Based Violence in Pakistan. 2011.

30. Ali PA, O'Cathain A, Croot E. Influences of extended family on intimate partner violence: perceptions of Pakistanis in Pakistan and the United Kingdom. J Interpers Violence 2018: 0886260518785378.

31. Zakar R, Zakar MZ, Hornberg C, Kraemer A. Coping strategies adopted by pregnant women in Pakistan to resist spousal violence. Int J Gynecol Obstet 2012; 116: 77-8.

32. Zakar R, Zakar MZ, Krämer A. Voices of strength and struggle:
Women's coping strategies against spousal violence in Pakistan J Interpers Violence 2012; 27: 3268-98.

33. Roomani FZ, Tayyab F, Kamal N, Siddique K. Role of Women in Perpetuating Violence against Women: Case Studies of Domestic Violence Victims. Pakistan Journal of Social Sciences (PJSS) 2016; 36: 1185-95

34. Rai A, Choi YJ. Socio-cultural risk factors impacting domestic violence among South Asian immigrant women: A scoping review. Aggression and Violent Behavior. 2018; 38: 76-85. 